\title{
Gregory P. Tschebotarioff, Dr Ing 1899-1985
}

Gregory P. Tschebotarioff, world renowned for his many contributions to the field of soil mechanics and foundation engineering, died on 22 April 1985 in Holland, Pennsylvania. The son of General Porphyry G. Tschebotarioff and Valentina Doubiagsky Tschebotarioff, he was born on 15 February 1899 in Pavlosk, Russia. His father was an officer in the Cossack Guard Battery and his mother was a close friend of the Russian Empress and her two daughters, the Grand Duchesses Olga and Tatiana Nikolayevna. He graduated from the Imperial Law School in Petrograd, Russia, in 1916 and went into the Russian Army until 1917. When the revolution began and the Bolsheviks took power, he joined the Grand Army of the Don and fought with the White Russians against the Red Army until 1920.

His engineering studies which began in Russia were continued in Germany, where he earned the Diplom-Ingenieur degree in 1925 and the Doktor-Ingenieur degree in 1952. Structural engineering projects in Paris, Berlin, Bremen, Hamlen and Cairo occupied his attention from 1925 to 1929 . In 1929 he began his specialization in soil mechanics research and foundation engineering. For seven years thereafter he specialized in foundation work in the Egyptian Government Service. Since 1936 he participated actively in numerous international conferences on soil mechanics and foundation engineering, including the First International Conference at Harvard, in 1936.

From 1937 until 1964 he was a member of the Princeton University Faculty, where he taught and lectured on civil engineering and where he organized a soil mechanics laboratory and courses on soil and foundation engineering. At Princeton, he also organized and was in charge of pioneering research projects on the effects of vibration of soils for the Civil Aeronautics Administration. His work on large-scale model tests on retaining walls, anchored bulkheads and other waterfront structures for the Bureau of Yards and Docks and for the Office of Naval Research attracted world-wide attention and acclaim.

He married Florence D. Bill, Princeton, New Jersey, in 1939.

In his years at Princeton, he wrote many professional papers and discussions on various aspects of this field. He authored Soil mechanics,

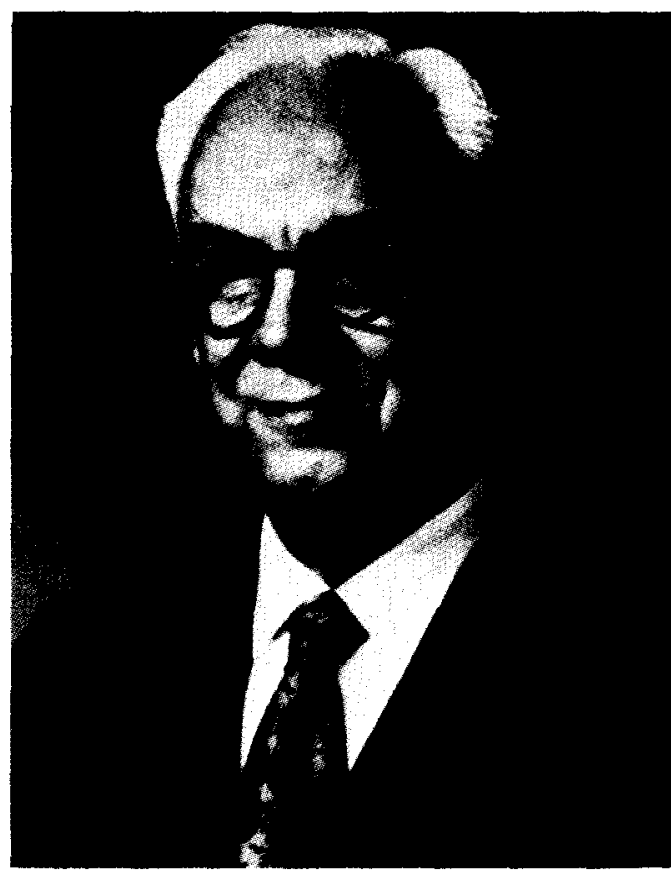

Dr G. P. Tschebotarioff

foundations and earth structures, a technical best selling textbook classic followed by Foundations, retaining \& earth structures. He contributed to the McGraw-Hill book Foundation engineering.

$\mathrm{He}$ also wrote an autobiography, Russia my native land, soon after he participated in the first official USA-USSR scientific exchange. Though he fought with the White Army during the Russian Revolution, and was a staunch citizen of the United States, he became the victim of harrassment during the McCarthy era when he denounced what he called the malevolent distortions of Russian history emanating from sources close to our US propaganda policies'.

Throughout his teaching career he engaged in consulting work and in 1955 became an Associate of King and Gavaris, Consulting Engineers, where he was in charge of soils and foundation work until 1970.

Dr Tschebotarioff retired from his professorship in 1964. In 1974, Dr Tschebotarioff donated his technical library and personal archives to Purdue University, including his students' theses, his consulting reports, the pro- 
ceedings of diverse international and regional conferences and many early geotechnical engineering classes in the German and Russian languages. The collection is housed in the Tschebotarioff Library-as part of the geotechnical engineering area at Purdue -along with a draft manuscript of his last book, Civil engineering on four continents. The collection is open to visitors by appointment.

He continued his consulting work including his 16 year participation as an Associate in the regular highway and harbour engineering work of King and Gavaris on three continents and investigations directly for other consulting engineers, construction firms, and federal and state agencies. These investigations were concerned with some specially interesting and complex soil and foundation problems encountered, including failures.

In 1959, he was awarded in Belgium the honorary Docteur Honoris Causa degree. A winner of the Karl Terzaghi Award, he was also named to Sigma Xi. According to the citation that pro- claimed him an Honorary Member of the American Society of Civil Engineers in 1977, Dr Tschebotarioff 'advanced the art of soil and foundation engineering through basic research and innovative practice, while fostering good will and mutual understanding among all people'.

He was active in the National Society of Professional Engineers, the American Historical Association and the American Association for the Advancement of Slavic Society. His many contributions to American Society of Civil Engineers' publications were climaxed by his presentation of the Second Martin Kapp Memorial Lecture of the Metropolitan Section, given on 21 January 1976. His talk 'Half a century of soil mechanics-some thoughts for the future in light of the past' received a standing ovation from a crowd of 150 engineers attending the presentation.

He is survived by his wife, Florence D. Tschebotarioff, and a sister, Valentine Bill.

G.A.L., P.T.G. 